\title{
Konstruksi Identitas Kultural Masyarakat Pluralis dalam Terpaan Globalisasi
}

\author{
PAWITO ${ }^{1}$, DRAJAT TRI KARTONO ${ }^{2}$ \\ ${ }^{1}$ IImu komunikasi Universitas Sebelas Maret, 2 Jurusan Sosiologi Universitas Sebelas Maret, Surakarta \\ email: drajat@yahoo.co.id
}

\begin{abstract}
This article aims to consider the construction of cultural identity through communication process within globalization era. The article based on qualitative research to look at communicatioan procces in which the cultural identity construction is taken place. The recent research focus on cultural identity of community living along the sea area, named Kaliwungu sub district, Kendal, Central of Java. This research conclude that cultural identity constructed by people of Kaliwunggu is influenced by global mass media. Televisioan as main media has good and bad impact toward people of Kaliwungu. Nevertheless, their tradition, local people forum and central mosque has been achore in which local value and tradition is maintained.
\end{abstract}

Keywords: cultural identity, communication, globalization

\begin{abstract}
Abstrak. Artikel ini mengkaji tentang konstruksi identitas budaya melalui proses komunikasi di era global. Kajian ini disusun berdasarkan hasil penelitian kualitatif dengan strategi studi kasus di daerah pesisir kecamatan Kaliwunggu Jawa Tengah yang berkarakteristik plural dari segi agama, etnis dan ekologis. Hasil penelitian ini menunjukkan bahwa identitas kultural dikonstruksi secara sosial oleh masyarakat Kaliwungu dengan pengaruh media massa global. Televisi sebagai media global yang paling utama berpengaruh pada masyarakat. Pengaruhnya dinilai dapat menjadi positif dan negatif bagi masyarakat. Namun demikian, pertahanan identitas kultural dilakukan melalui tradisi masyarakat, dalam bentuk kelembagaan forum perkumpulan masyarakat dan masjid yang menjadi pilar pertahanan nilai dan tradisi masyakat lokal didalam eraglobal.
\end{abstract}

Kata Kunci: identitas kultur, komunikasi, globalisasi

\section{Pendahuluan}

Kajian mengenai identitas kultural terkait dengan komunikasi dalam konteks globalisasi di Indonesia nampaknya belum banyak dilakukan apalagi dalam kaitan nuansa komunitas keislaman yang bersifat pluralis secara etnis. Dalam situasi seperti ini maka karya-karya seperti oleh Rummens (2001), Tomlinson (2003), Henighan (2002) dan Lechner (2002) sangat membimbing penelitian ini. Permasalahan ini berpusat pada pandangan Pawito yang memandang identitas kultural sebagai konsentrasi. Kemudian Pawito (2010: 9) mencermati bahwa identitas kultural sebenarnya lebih merupakan konstruksi sosial budaya dari masyrakat dan/atau bangsa yang terbentuk oleh gabungan dari berbagai faktor termasuk misalnya faktor sejarah, budaya, etnis, bahasa, agama dan kondisi-kondisi wilayah geografis." Bertolak dari pandangan demikian maka identitas kultural bukan merupakan suatu entitas yang instan tetapi terbangun melalui proses-proses interaksi berbagai unsur sebagaimana di atas dikemukakan, dan jelas bahwa untuk hal tersebut melibatkan rentangan waktu yang panjang. Dari ini maka dapat dipahami bahwa suatu masyarakat biasanya memiliki identitas kulturalnya masing-masing yang lama terpateri di dalam setiap sanubari warga masyarakat bersangkutan. Karena ini pula maka setiap masyarakat berupaya mempertahankan, melestarikan, dan mengembangkan identitas kulturalnya.

Dalam pada itu Lechner (2002) mengkaji dari globalisasi terhadap identitas nasional khususnya di Negeri Belanda dan berkesimpulan bahwa di Negeri Belanda sifat identitas bervariasi. Tumbuhnya variasi sifat identitas, menurut Lechner, pada intinya merupakan proses-proses dialektika antar unsur-unsur budaya global dengan unsur-unsur budaya lokal dan nasional. Namun demikian menariknya kajian ini bahwa kebijakankebijakan yang dibuat oleh pemerintah Negeri 
Belanda diidentifikasi, misalnya, kalau kebijakan di dekade 1980-an dibuat terutama dengan maksud untuk membangun dan memperkuat solidaritas, memeratakan keadilan, dan mengokohkan prinsip universalisme; maka kebijakan yang dibuat di dekade 1990-an nampak oleh Lechner (2002: 26) lebih dimaksudkan untuk memerkuat partisipasi, mengukuhkan tanggungjawab individu warga negara di samping juga untuk memperkuat solidaritas.

Kemudian Henighan (2002) mengamati gejala-gejala pengembangan identitas kultural yang terjadi di Kanada dalam konteks globalisasi. Henighan melihat bahwa ancaman nyata terhadap budaya Kanada sebenarnya bukan komunikasi transnasional yang sampai tingkat tertentu nampaknya mempenetrasi, dan bukan juga teknologi baru termasuk teknologi media; tetapi musuh paling nyata bagi budaya Kanada sebenarnya adalah kecenderungan penyeragaman (uniformity) budaya yang didesakkan oleh media internasional yang didominasi oleh media Amerika telah membanjiri publik di Kanada dengan beritaberita dan paket hiburan yang berceritakan dan bergaya Amerika. Bahkan berkenaan dengan pemberitaan, Henighan mengamati, media Amerika mempenetrasi publik Kanada dengan informasi-informasi dan citra yang jelas erat terkait dengan mitos-mitos Amerika (Henighan, 2002: 10)

Pandangan tentang komunikasi demikian dapat dikatakan memiliki kesejalanan apa yang dikatakan oleh Fiske (1990) bahwa komunikasi lebih merupakan social interaction through message. Dalam pemikiran demikian maka komunikasi sangat lekat dengan identitas kultural (lihat juga dan bandingkan, misalnya, dengan Pawito, 2007: 18-19; Littlejohn, 2002: 6-9).

Kondisi di Kanada tidak pelak juga dialami di Indonesia sebagai negara berkembang yang sangat terbuka dengan proses globalisasi. Riset ini melakukan studi proses tersebut.

Diskusi atau tidak, globalisasi sudah berlangsung bahkan sudah sejak lama dimulai. Bahas Inggris sudah sejak lama digunakan oleh banyak masyarakat/bangsa. Pakaian stelan jas juga sudah lama dikenakan oleh kalangan luas masyarakat dunia, makan pagi dengan roti beroleskan mentega dan diiring dengan minum susu sudah lama dikenal luas termasuk di Indonesia. Paham demokrasi sebagai perangkat sistem untuk pengaturan kekuasaan pemerintahan negara juga sudah sejak lama diadopsi oleh banyak sekali masyarakat/bangsa di dunia, walau di sana-sini memiliki variasi-variasi karena faktor-faktor sejarah dan juga budaya masyarakat/bangsa bersangkutan. Semua ini menunjukkan adanya pengaruh dan sekaligus juga proses globalisasi yang sebenarnya sudah sejak lama berlangsung yang barangkali tanpa banyak disadari. Hal demikian masih berlangsung hingga hari ini, dan bahkan nampaknya semakin kuat mempenetrasi. Pengaruh atau dampak dari globalisasi juga semakin luas melanda masyarakat dunia termasuk masyarakat Indonesia belakangan ini mencakup bidang ekonomi, politik, budaya, dan informasikomunikasi.

Belakangan semakin terasa bahwa gejala dan proses globalisasi nyaris tak terelakkan, melanda masyarakat di bagian bumi manapun termasuk di Indonesia, bahkan juga termasuk masyarakat Kaliwungu Kabupaten Kendal Provinsi Jawa tengah, yang sangat diwarnai oleh kultur I slam. Disamping itu, secara geografis masyarakat Kaliwungu menempati kawasan pesisir yakni pesisir utara Jawa Tengah. Gejala globalisasi ini di Kaliwungu dapat diamati misalnya melalui banyaknya baliho dan papan reklame yang mengiklankan berbagai produk buatan Multinational Cooporation (MNC) yang pada dasarnya adalah produk budaya global, termasuk, misalnya, iklan produk minuman ringan Coca Cola. Iklan produk toileteris buatan Unilever (seperti sampho, pasta gigi,dan sabun mandi), dan juga iklan produk air minum kemasan seperti Aqua Danone.

Sementara itu, sampai tingkat tertentu setidaknya, dikalangan warga masyarakat Kaliwungu berkembang pola-pola baik dalam berbahasa, berbusana, dan beradat-kebiasaan yang nampaknya mencerminkan identitas kultural mereka terutama terkait denga nilai-nilai keislaman. Masyarakat Kaliwungu kendati sebenarnya merupakan masyarakat dengan dominasi kultural Islam (Kaliwungu dikenal sebagai Kota Santri), namun sedikit banyak memiliki karakter pluralis, di samping juga masyarakat pesisir. Di Kaliwungu terdapat penduduk dengan beragam etnis, dan relatif sangat sedikit dalam hal jumlah.

Masyarakat Kaliwungu juga nampak mengembangkan berbagai forum komunikasi yang dapat dikatakan memiliki signifikansi dengan upaya melestarikan, mempertahankan, dan kalau mungkin mengembangkan identitas kultural ini, seperti forum silaturahmi, walimahan, pertemuan keturunan (trah), dan perkumpulan kelompok pengajian khususnya bagi kalangan masyarakat Jawa Islam.

Dari hal-hal sebagaimana baru saja dikemukakan di atas, nampak sangat menarik untuk meneliti persoalan bagaimana keberadaan identitas kultural masyarakat Kaliwungu di tengah kuatnya penetrasi budaya global yang difasilitasi oleh media massa, dan bagaimana pula forum komunikasi, termasuk media massa, telah mengambil peran-peran tertentu terkait dengan pelestarian dan pengembangan identitas budaya mereka.

Artikel ini membahas persoalan globalisasi 
di bidang budaya dan mengambil titik berat permasalahan tentang bagaimana keberadaan identitas kultural masyarakat Kaliwungu Kabupaten Kendal Provinsi Jawa Tengah, yang notabene adalah masyarakat dengan kultur I slam dan sekaligus juga pesisir; namun sedikit banyak diwarnai oleh sifat pruralis (dari segi etnis); bagaimana masyarakat Kaliwungu menjaga atau melestarikan (berupaya mengembangkan) identitas kultural mereka, ketika mereka dihadapkan pada derasnya arus globalisasi. Secara lebih rinci lacakan penelitian ini meliputi (1) bagaimana masyarakat Kaliwungu berupaya melestarikan/menjaga identitas kultural mereka terutama dalam hal berbahasa, berpakaian; (2) beradat-kebiasaan ketika mereka dihadapkan pada derasnya penetrasi nilai-nilai budaya global, dan bagaimana bentuk-bentuk atau forum komunikasi dikembangkan oleh masyarakat Kaliwungu dalam berbagai kesempatan yang memiliki signifikansi dengan upaya pelestarian identitas kultural; (3) Bagaimana pandangan atau penilaian masyarakat Kaliwungu mengenai globalisasi; (4) Bagaimana pandangan atau penilaian masyarakat Kaliwungu mengenai peran media massa dalam proses-proses globalisasi.

\section{I dentitas Kultural dan Globalisasi}

Rummens (2001), misalnya, mengemukakan pengamatan bahwa identitas kultural (cultural identity) dapat dimaknai menurut berbagai cara termasuk, misalnya, sebagai penanda atau pembeda yang bersifat khas, walau sering terkesan imajinatif; Yang ada atau melekat pada suatu masyarakat (termasuk masyarakat bernegara/berbangsa). Dengan identitas kultural yang dimaksud dapat dibedakan antara masyarakat bersangkutan dengan masyarakat lain (Rummens, 2001). Bertolak dari pengamatan Rummens, maka dapat dipahami betapa identitas kultural biasanya dirasakan sangat penting oleh warga masyarakat/ bangsa bersangkutan di manapun terutama oleh karena identitas kultural dapat berfungsi, selain sebagai penanda atau pembeda, juga berfungsi sebagai pengikat kebersamaan (yang mempersatukan segenap warga komunitas), sebagai kekayaan dan kebangsaan (warisan budaya yang memberikan semacam roh, yang karena itu harus senantiasa dipelihara, dilestarikan dan dikembangkan), dan juga sebagai kekuatan yakni kekuatan penggerak dalam kehidupan dan mencapai tujuan baik secara internal sesama warga komunitas maupun eksternal ketika berinteraksi dengan masyarakat/bangsa lain.

\section{Komunikasi dan I dentitas Kultural}

Terdapat setidaknya lima jenis komunikasi antar manusia yakni (a) komunikasi antarpribadi, (b) komunikasi kelompok; (c) komunikasi organisasi; (d) komunikasi massa; dan (e) komunikasi budaya.

Diantara lima jenis komunikasi maka kajian mengenai komunikasi dalam kaitan dengan identitas kultural pada kenyataannya lebih sering menekankan kepada komunikasi (dengan menggunakan) media massa dan terkesan mengabaikan jenis komunikasi yang kelima (komunikasi budaya). Komunikasi massa merupakan bentuk komunikasi yang melibatkan partisipan sangat luas dan heterogen dengan basis pranata sosial media massa, termasuk, misalnya, surat kabar, majalah, radio, televisi, dan internet (lihat, misalnya, Pawito, 2007: 1-19). Berbagai kajian mengenai media massa, misalnya, oleh Pawito (2008), berkesimpulan bahwa media massa memiliki kekuatan-kekuatan tertentu (di samping fungsi-fungsi yang kerapkali disebut dan/ atau dikonfirmasi oleh banyak peneliti), termasuk misalnya, (a) mengkonstruksi atau mendekonstruksi realitas hingga tercipta citra, pandangan, dan keyakinan-keyakinan tertentu pada khayalak terkait dengan peristiwa dan/atau persoalan tertentu; (b) mengagregasikan dan mengartikulasikan kepentingan, aspirasi-aspirasi, atau tuntutan-tuntutan; dan (c) memproduksi dan mereproduksi identitas budaya.

\section{Globalisasi dan Komunikasi}

Konsep globalisasi pada kenyataannya diartikan secara beragam oleh para ahli. Albrow (1990, dikutip oleh McQuail, 2002: 239), memandang globalisasi lebih merupakan proses menuju suatu dunia dengan karakter perubahan orientasi budaya yang berlangsung secara terusmenerus yang membawa manusia kepada the whole earth as physical enviroment, everyone living as world citizens, consumers and producer with a common interst in collective action to solve global problems.

Pandangan di atas memberikan kesan pentingnya mengupayakan kerjasama di antara sesama penghuni bumi di manapun demi lestarinya kehidupan. Namun demikian, pada kenyataannya sebagaimana kerapkali dikritik oleh banyak kalangan masyarakat negara sedang berkembang dan kalangan-kalangan kritis maka globalisasi dirasakan lebih menampakkan kesan bengis, eksploitatif, dan hegemonik oleh negara maju atas negara sedang berkembang. Kalangan-kalangan yang lebih mendasarkan diri pada pemikiran Marx bahkan lebih melihat globalisasi sebagai pengusung nilai-nilai neo-liberalisme, mengukuhkan imperialisme budaya, dan bahkan Amerikanisasi corak budaya.

Kemudian, kalangan postmodernis memiliki pandangan yang lain lagi, yakni globalisasi 
merupakan gejala tumbuh berkembangnya budaya bersama (common culture), terutama menyangkut pola-pola konsumsi dan gaya hidup (Featherstone, 1991, dalam McQuail, 2002: 239). Ferguson dalam pada itu melihat globalisasi sebagai:

both a journey and a destination: it signifies an historical process of becoming, as well as an economic and cultural result; that is arrival at the globalized state" (Ferguson, 2002: 239).

Para peneliti pada umumnya menyepakati pandangan bahwa globalisasi membawa dampak terhadap identitas kultural secara positif ataupun negatif. Malgaj (2009), misalnya, mengatakan bahwa salah satu dampak negatif dari globalisasi adalah meluasnya perusahaan-perusahaan multinasional (multinational corporation, MNC). Hal demikian secara langsung membawa konsekuensi antara lain berupa ukuran-ukuran (standar) tertentu mengenai barang-barang dan jasa layanan jasa, cara-cara produksi, pola konsumsi, dan akhirnya juga perilaku dan gaya hidup.

Di sisi lain globalisasi juga membawa dampak positif terhadap identitas kultural. Malgaj (2009) dalam kaitan ini mengamati bahwa pada kenyataannya globalisasi seringkali juga tidak menghancurkan sama sekali identias kultural, tetapi justru menciptakan dan memperluas identitas kultural.

Globalisasi, dengan kata lain, telah mendorong masyarakat negara sedang berkembang semakin menyadari arti penting dari identitas kulturalnya, secara terus-menerus mencari akar dan sejarahnya, dan berusaha sekuat tenaga memelihara, melestarikan dan mengembangkannya.

Media massa mengamplifikasi nilai-nilai budaya global yakni nilai-nilai budaya masyarakat negara maju, terutama Amerika, ke masyarakat negara sedang berkembang termasuk Indonesia. Dalam hubungan ini media massa memfasilitasi globalisasi (mengusung dan/atau mengamplifikasi nilai-nilai budaya global), seperti dikatakan oleh Barker (1999: 7), tidak dalam pengertian secara serta merta mengkonstrusi identitas kultural seperti jarum suntik yang digunakan dokter untuk memasukkan vaksin kedalam tubuh pasien sehingga segala sesuatunya berlangsung otomatis. Namun, media massa menyediakan bahan-bahan berupa nilai-nilai budaya global yang kemudian diinterpretasi oleh khayalak dengan referensi pengalaman hidup serta budaya saling berinteraksi dalam proses-proses pembentukan dan atau pengembangan identitas kultural suatu masyarakat. Hal ini mengingatkan kebenaran pandangan bahwa identitas budaya sebenarnya bukan merupakan suatu entitas yang universal, fix, dan final akan tetapi senantiasa dalam proses menjadi. Karena ini maka proses pembentukan dan atau pengembangan identitas kultural kerapkali melibatkan kecenderungan-kecenderungan tertentu seperti asimilasi, akulturasi, atau penolakan yang diwujudkan dengan pengembangan budaya tandingan (counter culture). Sehingga penting untuk memeroleh penekanan bahwa derasnya arus globalisasi terutama karena globalisasi yang difasilitasi oleh media massa.

Sebagaimana luas dipahami penelitian kualitatif lebih dimaksudkan untuk memberikan gambaran (description) dan pemahaman (understanding) mengenai bagaimana dan mengapa gejala atau realitas sosial terjadi atau berkembang dan tidak dimaksudkan untuk memberikan penjelasan, mengontrol, dan memprediksi gejalagejala (Pawito, 2007: 35). Kemudian mengenai studi kasus, seperti dikatakan Patton (2002: 447), merupakan upaya mengumpulkan, kemudian mengorganisasikan, dan menganalisis data tentang kasus-kasus tertentu berkenaan subjek yang diteliti dengan tetap berpegang pada prinsip holistik, interpretif, dan kontekstual. Studi kasus pada umumnya melacak beberapa hal penting berkenaan dengan subjek penelitian (notabene adalah kasus yang diteliti) termasuk, misalnya, (a) keadaan atau sifat kasus yang sedang diteliti; (b) latarbelakang sejarah muncul dan berkembangnya kasus; (c) konteks berkembangnya kasus (misalnya sosial, ekonomi, budaya); dan (d) kasus lain yang mungkin dapat diketahui (misalnya dari sumbersumber literatur) yang dapat membantu memahami kasus yang sedang diteliti.

Kandungan laporan penelitian dengan menggunakan studi kasus, karena itu, memuat pokok-pokok dari setidaknya keempat hal penting di atas. Dalam ungkapan Miller (1996: 167), studi kasus adalah:

in-depth analyses of single or few communities, organizations, or persons' lives. They involve detailed and often subtle understandings of the social organization of everyday life and person's live experience.

Karena strategi ini biasanya memusatkan perhatian pada hal-hal yang dianggap unik atau khas dan terjadi secara alamiah, dalam Arti tidak ada campur tangan oleh peneliti seperti dalam penggunaan metode eksperiman, misalnya, maka studi kasus sering dinilai sebagai suatu studi yang (juga) bersifat natural.

Dalam hubungan ini maka dapat dikatakan bahwa studi kasus di Kaliwungu karena masyarakat Kaliwungu dipandang unik dan khas karena beberapa hal termasuk: karakter masyarakat pesisir dengan budaya yang sangat diwarnai oleh nuansa keislaman walau sebenarnya bersifat pluralis (di kota kecil ini tinggal etnis J awa, keturunan Tionghowa, keturunan Arab), dan 
menghuni wilayah di dekat wilayah pesisir yang biasanya memiliki sifat langsung (blak-blakan) dalam berkomunikasi, dan sejauh ini dapat dikatakan nyaris tak pernah terjadi konflik antarethnis di kota ini kendati terdiri dari beberapa keturunan etnis.

Teknik Pengumpulan Data, dilakukan dengan Teknik Observasi, Teknik Wawancara, dan FGD atau Focus Group Discussions yang merupakan metode kualitatif, yang lazim digunakan untuk melacak hal-hal tertentu yang nampaknya ingin ditonjolkan atau menjadi prioritas bagi responden atau subyek penelitian. Kehadiran seorang moderator yang memfasilitasi jalannya diskusi serta mengajukan pertanyaan kepada responden akan lebih memungkinkan peneliti memeroleh data yang memadai sebagaimana diharapkan. Penelitian ini melibatkan tiga kelompok partisipan untuk pelaksanaan FGD yakni melibatkan kelompok masyarakat santri, orang dewasa kebanyakan (general public), dan remaja.

Dari sembilan kelurahan ini dipilih (diambil secara purposif) dua kelurahan di antranya sebagi titik berat pengamatan yakni: Nolokerto dan Krajan Kulon. Penentuan ini dibuat berdasarkan pertimbangan kesesuaian dengan tujuan penelitian, yakni untuk memberikan gambaran dan pemahaman mengenai gejala pelestarian/ pengembangan identitas kultural dalam kaitan dengan komunikasi dan globalisasi. Warga masyarakat Nolokerto lebih banyak hidup dengan mata pencaharian di sektor pertanian (lebih bersifat agraris, rural). Sementara warga masyarakat Krajankulon lebih banyak hidup dari sektor perdagangan (lebih bersifat urban). Penentuan secara purposif demikian diyakini akan menghasilkan data serta kesimpulan yang valid.

Sesudah ini analisis data berlanjut ke tahap uji validasi yakni dengan menggunakan teknik triangulasi sebagaimana lazimnya penelitian kualitatif. Teknik triangulasi, sebagaimana dipahami secara luas, bukan dimaksudkan untuk menguji data mana yang lebih benar di antara data yang diperoleh ketika data yang didapat ternyata berbeda atau bahkan mungkin bertolak belakang satu dengan lainnya. Akan tetapi langkah triangulasi lebih merupakan upaya menunjukkan bukti empirik, untuk meningkatkan pemahaman terhadap realitas atau gejala yang diteliti dengan memberikan perspektif yang beragam demi analisis dan kesimpulan yang lebih komprehensif.

Seperti diketahui bahwa dalam penelitian kualitatif dikenal beberapa jenis teknik triangulasi yakni triangulasi data, triangulasi peneliti, triangulasi teori, dan triangulasi metode (Patton, 2002: 555-563). Dengan teknik triangulasi data/ sumber maka penelitian ini mengakses sumbersumber data yang bervariasi, untuk memeroleh data berkenaan dengan persoalan yang sama, sehingga dapat diperoleh perspektif pandangan dan/atau analisis yang bervariasi. Triangulasi metode diterapkan dengan cara menyandingkan temuan data dari hasil penggunaan metode yang ada. Tahap selanjutnya adalah mengemukakan interpretasi-interpretasi terhadap hasil-hasil analisis yang dilakukan sebelumnya, dengan merujuk pandangan-pandangan teoritik dan/atau temuan-temuan penelitian.

\section{Upaya Menjaga/ Melestarikan I dentitas Kultural}

Artikel ini memberikan gambaran dan pemahaman mengenai gejala identitas kultural terkait dengan komunikasi dan globalisasi khususnya yang ada/berkembang di masyarakat Kaliwungu. Bagaimana masyarakat Kaliwungu berupaya menjaga, melestarikan, dan mengembangkan identitas kultural mereka ketika mereka dihadapkan pada derasnya penetrasi budaya global.

\section{Penggunaan Bahasa}

Dalam hal berbahasa, masyarakat Kaliwungu cenderung egaliter, berbicara langsung (blak-blakan, tidak/kurang eufemistik) ciri khas masyarakat pesisir, namun tetap ramah dan santun, dan biasanya menunjukkan nuansanuansa keislaman di sana-sini. Bahasa J awa Ngoko disertai kromo-madyo merupakan pola paling umum/luas dijumpai di Kaliwungu. Pola berbahasa seperti ini sangat umum dijumpai baik di pasar, di sawah/ladang, di sekolahan, maupun di masjid diantara sesama para jama'ah. Komunikasi yang terjadi di antara sesama buruh, sesama petani, antara pedagang dengan pelanggan yang sudah lama saling mengenal, dan sesama sahabat (peer group) biasanya menggunakan bahasa jenis ini.

Kemudian untuk konteks yang lebih mendekati urusan pekerjaan di kantor maka penggunaan bahasa Jawa Ngoko biasanya bercampur kromo madyo dan sering masih harus bercampur dengan bahasa Indonesia. Bahasa J awa kromo madyo (bukan ngoko) lazim digunakan ketika berbicara dengan orang yang dihormati dan atau orang yang baru saja dikenal, atau digunakan oleh khotib ketika menyampaikan khotbah J umah di banyak masjid jami' di Kaliwungu, kecuali Masjid Besar Al-Muttaqien. Bahasa yang digunakan oleh khotib di Masjid Besar Al-Muttaqien Kaliwungu ketika menyampaikan khotbah biasanya menggunakan bahasa Indonesia. Sedangkan bahasa Jawa kromo-inggil dijumpai secara sepotong-sepotong bercampur dengan kromomadyo dan bahasa Arab dengan dominasi tetap menggunakan bahasa Indonesia.

Bahasa arab sebagai bahasa pengantar atau bahasa percakapan sehari-hari sangat jarang 
digunakan di kalangan kebanyakan warga masyarakat Kaliwungu, bahkan di kalangan warga keturunan Arab sekalipun. Bahasa Arab memang digunakan oleh sebagian warga masyarakat Kaliwungu namun lebih bersifat terbatas yakni dalam rangka belajar dan mempelajari bahasa Arab, terutama di madrasah dan di pondok pesantren. Bahasa Arab cenderung tidak digunakan dalam kehidupan sehari-hari. Namun kosakata bahasa Arab sering kali digunakan dalam kehidupan sehari-hari oleh warga penduduk Kaliwungu. Seperti, misalnya, ucapan salam, ucapan syukur, ketika mereka saling menjalin hubungan komunikasi. Dalam hubungan ini kosa kata bahasa Arab yang digunakan seolah lalu memiliki fungsi perekat sesama pengguna bahasa dan akhirnya menjadi identitas kultural masyarakat Kaliwungu yang agamis I slam).

Hasil dari pencermatan hal-hal diatas dapat dikatakan bahwa lambang-lambang bahasa memang digunakan dalam berkomunikasi untuk mewakili pikiran, perasaan, atau obyek. Namun lebih dari itu, bahasa nampaknya juga merupakan perekat kebersamaan, dan mengukuhkan identitas kultural masyarakat penggunanya.

\section{Cara Berbusana}

Secara umum dapat dikatakan bahwa cara berbusana kebanyakan warga masyarakat Kaliwungu lebih memberikan kesan keislaman, terutama, yakni baju koko dan peci (songkok) hitam bagi para lelaki dewasa, dan baju jilbab (dengan mode yang bervariasi) bagi kaum perempuan.

Untuk kaum laki-laki pada umumnya menggunakan baju koko/ kemeja lengan panjang dan sarung tenun/ celana pangjang berwarna gelap lengkap dengan peci ketika pergi ke masjid atau bersilaturahmi kepada tetanggga/ kerabat yang lokasinya dekat. Sedangkan jubah berwarna putih lengkap dengan surban bewarna putih biasanya dikenakan laki-laki berusia lebih tua dan lazimnya lebih banyak dikenakan para Kyai/ulama sepuh termasuk pengasuh Pondok Pesantran.

Sedangkan Kopiah atau peci putih lazim digunakan oleh lelaki yang sudah Haji. Kalangan remaja pada umumnya mengenakan busana yang lebih trendy/modis meskipun tidak sering misalnya kaos bertema tim kesebelasan sepak bola. Sedangkan yang lazim digunakan adalah kemeja lengan pendek/panjang dan celana panjang.

Untuk kaum perempuan menggunakan jilbab dengan model yang berkaitan dengan umur dan kepentingan aktivitas sehari-hari. Perempuan berusia muda biasanya menggunakan jilbab yang lebih trendy misalnya: menggunakan bahu atasan T-Shirt lengan panjang/ kemeja panjang, bagian bawah celana panjang/ rok bahan jeans/katun. decker panjang. Sedangkan perempuan berusia dewasa dan lebih tua kerap kali menggunakan jilbab standart yang terdiri dari cidung, baju jilbab terusan (gamis) atau juga jilbab pedotan (baju atasan dan bawahan) yang motif dan warnanya tidak selalu serasi dimana bagian bawahan berupa celana panjang. Dipengaruhi oleh faktor kepentingan, Warga Perempuan Kaliwungu sama dengan masyarakat kota lainnya akan mengenakan jilbab lengkap beserta aksesori seperti bros, gelang, kalung dan make-up minimalis seperti bedak, lipstik tak lupa minyak wangi ketika mengahadiri suatau acara walimahan (kenduri, perjamuan, kondangan) dan silaturahmi seperti lebaran. Cara berbusanan ini mengukuhkan identitas kultural Islam masyarakat Kaliwungu yakni bercorak keislamam Indonesia yang boleh jadi dapat berbeda dengan keislaman di negara-negara Arab dan Timur Tengan atau negara lainnya.

\section{Adat Kebiasaan (tradisi)}

Terdapat beberapa adat kebiasaan yang berkembang di kalangan Masyarakat Kaliwungu beberapa diantaranya yang menonjol adalah tradisi silaturahmi, syawalan, sadranan, dan weh-wehan yang sangat diwarnai oleh nilai-nilai keislaman. Kenyataan bahwa setiap pelaksaan adat kebiasaan meniscayakan kebersamaan. Maka adat kebiasaan ini kemudian juga menjadi bentuk atau forum komunikasi di antara sesama warga masyarakat Kaliwungu.

\section{Tradisi Silaturahmi}

Adat kebiasaan atau tradisi silaturahmi merupakan tradisi yang paling umum berkembang dikalangan masyarakat Kaliwungu. Inti dari tradisi silaturahmi adalah orang saling bertemu dan menyambung/melestarikan jalinan hubungan kasih-sayang atau persaudaraan dengan orang lain. Adat kebiasaan ini di kalangan masyarakat Kaliwungu berkembang dalam wujud yang sangat beragam sehingga melibatkan spektrum yang luas mulai dari kunjungan seseorang/keluarga kepada orang/keluarga lain di hari-hari biasa untuk suatu maksud/kepentingan, berhalal-bi-halal di hari Lebaran, hingga menghadiri undangan termasuk undangan walimah misalnya hajatan pernikahan. Ajaran bersilaturahmi sangat memperoleh penekanan dalam agama Islam baik dalam beberapa ayat di Al-Qur'an maupun Hadist.

\section{Tradisi Syawalan}

Tradisi syawalan merupakan tradisi yang dapat dikatakan spektakuler di Kaliwungu. Setelah bulan Ramadhan masyarakat menjalankan ibadah puasa maka pada 1 Syawal masyarakat merayakan lebaran dengan berangkat shalat Ied ke lapangan/ masjid dengan menggunakan pakaian terbaik yang 
dimiliki lengkap dengan asesori. Kaum laki-laki menggunakan baju koko dan sarung tenun/celana panjang serta kupiah hitam/ putih khusus yang sudah berhaji. Kaum perempuan mengenakan baju muslimah (jilbab) dengan aneka warna dan model. Kemudian merayakan Lebaran di rumah bersama sanak saudara dengan hidangan istemewa yang tidak sama dengan hari-hari biasanya seperti lontong opor, ayam, sambel goreng, dll.

Tradisi syawalan yang sebenarnya adalah pada hari ke - 7 setelah hari Raya Lebaran Iedul Fitri yaitu digelarnya prosesi Tradisi Syawalan di Masjid Agung Al-Muttaqien di pusat Kota Kaliwungu. Pada mulanya acara syawalan sebenarnya merupakan acara haul (peringatan tahunan wafatnya seseorang menurut tarikh bulan, dan menggunakan perhitungan Tahun Hijriyah) wafatnya Kiai Asyari (sering disebut Kiai Guru) tokoh penyebar agama Islam di kaliwungu. Lama kelamaan tradisi ini melebar hingga ke makam Sunan Katong (Pangeran Mandurarejo - tokoh Panglima Perang Mataram) dan juga Pangeran Pakuwaja; bahkan kemudian juga meluas lagi ke makam tokoh-tokoh lain kemudian seperti Kiai Mustofa, Kiai Musyafa', dan Kiai Rukyat. Puncak acara ditandai dengan penggantian klambu/luwur makam Kiai Asy'ari.

\section{Tradisi Sadranan}

Adat Kebiasaan sadranan dikenal luas dan dijalankan oleh kalangan luas masyarakat Jawa termasuk kalangan masyarakay Kaliwungu. Kata Sadranan (kata kerja dalam bahasa J awa nyadran) berasal dari kata yang memiliki makna dekat dengan kata dalam bahasa Arab ziarah namun lebih tertuju pada makam atau kompleks pemakaman, dan kemudian meluas ke tempat atau situs yang dikeramatkan. Dalam kenyataannya praktek atau pelaksanaan sadranan (atau nyadaran) kerapkali sangat berbeda antara yang berkembang di satu tempat dengan tempat lain. Pelaksanaan sadranan juga sering terjadi secara kolektif baik dalam pengertian kelompok dalam arti keluarga maupun kolektif warga masyarakat setempat. Khusus pelaksanaan sadranan yang dilakukan secara kolektif oleh warga masyarakat di Kaliwungu biasanya dipimpin oleh seorang tokoh yang dituakan yang biasanya sekaligus seorang Kiai (ulama) setempat.

Di Kaliwungu yang terjadi adalah bahwa tradisi nyadaran dilaksanakan secara bervariasi. Sebagian orang/keluarga datang ke makam dan berdo'a untuk yang dikubur di situ pada salah satu dari sore hari (setelah Ashar sampai menjelang Maghrib) di sepuluh hari terakhir bulan Ramadhan.

\section{Tradisi Weh-wehan}

Tidak diketahui dengan pasti kapan tradisi weh-wehan ( harfiah berarti saling memberi) mulai berkembang di Kaliwungu. Inti dari tradisi ini adalah pengungkapan kasih sayang kedalam bentuk memberikan suatu pemberian oleh seseorang (biasanya mempresentasikan sebuah keluarga) kepada orang lain (yang merupakan representasi dari keluarga lain). Artinya dengan tradisi wehwehan ini apa yang segera nampak adalah seseorang memberikan suatu pemberian kepada orang lain tetapi pemberian ini sebenarnya berlangsung dalam konteks keluarga ke keluarga.

Pemberian yang dimaksud yang paling khas adalah makanan yang disebut sumpil yaitu makanan terbuat dari beras seperti ketupat dengan bungkus daun bambu muda berbentuk segi tiga seperti limas. Bentuk segi tiga atau lias dari sumpil sebenarnya mengandung nilai yang mengisyaratkan tiga titik yang merepresentasikan jalinan hubungan yang semestinya manusia senantiasa menjaga keharmonisannya yakni manusia, Allah dan alam.

Makanan sumpil merupakan makanan khas Kaliwungu dan dibuat/dimakan ketika bulan Maulud (RabiulAwal) sebagai peringatan kelahiran $\mathrm{Nabi}$ Muhammad SAW yang telah membawakan ajaran agama Islam. Pesan moral yang terkandung dari tradisi weh-wehan ini disamping isyarat filosofik dakwah, juga pesan moral untuk berbagi kebahagiaan (antar yang kaya dan miskin, yang muslim dan nonmuslim), memupuk jalinan hubungan silaturahmi, dan memupuk kegemaran bersedekah.

\section{Bentuk-bentuk Forum Komunikasi}

Pada intinya, disetiap bentuk/forum komunikasi terdapat karakter khas yakni; banyak warga bertemu dan berkumpul, saling berbincang secara longgar tentang apa saja mulai dari masalah keluarga, masalah lingkungan sosial dan masyarakat mereka sendiri, gossip lokal, hingga masalah politik di samping sudah barang tentu adalah tentang hal berkenaan dengan kepentingan pokok acara pertemuan.

\section{Walimahan}

Kata walimahan dapat diartikan sebagai perjamuan. Namun spektrum dari makna istilah ini dapat meluas termasuk juga misalnya hajatan, kenduri, bahkan juga pesta. Kata walimah (yang kemudian menjadi kata benda dalam bahasa Indonesia walimahan) karena itu, seringkali digunakan dalam berbagai konteks termasuk misalnya walimatul 'urusy yang digunakan untuk menunjuk perjamuan/hajatan pernikahan, walimatul safar (dibaca: walimatussafar) digunakan untuk menunjuk perjamuan yang diselenggarakan ketika orang yang meyelenggarakan perjamuan hendak mengadakan perjalanan 
jauh misalnya hendak pergi Haji.

Para tamu pada acara khusunya walimahan pengantin, biasanya saling berbincang satu dengan yang lain mengenai perihal apa saja yang mereka tertarik membicarakannya termasuk persoalan pekerjaan, lingkungan, masalah sosial, dan politik terutama dikalangan para laki-laki. Kemudian gosip terkait dengan isu lokal seringkali terkesan mendominasi perbincangan terutama di kalangan para perempuan dan para ibu.

\section{Pertemuan Trah}

Pertemuan trah merupakan forum yang juga tergolong lazim diselenggarakan di kalangan masyarakat Kaliwungu. Penyelenggaraan acara seperti ini secara lebih istimewa biasanya mengambil momentum kepulangan warga desa yang bekerja merantau ke kota besar (terutama J akarta) yakni ketika mereka ini sedang mudik di hari Lebaran. Namun demikian sering juga kelompok trah menyelenggarakan pertemuan trahsecara periodik sesuai hari yang telah ditetapkan diluar momen Lebaran. Adat kebiasaan pertemuan trah memiliki karakter pokok bahwa banyak orang saling bertemu bersilaturahmi si suatu tempat yang sudah disepakati sebelumnya namun terbatas di kalangan keturunan (trah) seseorang tertentu, yakni anak-cucu beserta keluarganya dari seseorang yang disepuhkan atau ditokohkan.

Pada acara pertemuan trah sering kali dibahas mengenai berbagai hal termasuk kemungkinan-kemungkinan saling membantu oleh warga/keluarga trah yang kuat secara ekonomi kepada warga / keluarga yang lemah, diselenggarakan arisan, dan bahkan dibicarakan juga rencana untukbersama melakukan kegiatan misalnya menyumbang untuk pembangunan atau perbaikan masjid/mushola.

Pertemuan trah sebagai suatu bentuk/forum komunikasi dapat dikatan menyumbang upaya pelestarian identitas kultural dari berbagai hal yang diperbincangkan didalamnya seperti maslah keluarga, sosioal,dan nilai-nilai agama (Islam), begitupun dengan pakaian yang dikenakan oleh anggota Trah bernuansa I slam ketika acara serta bahasa yang digunakan yang kesemuanya memperteguh identitas kultural masyarakat Kaliwungu yang lebih bercorak Islam sementara nilai-nilai budaya global bertubi-tubi mempenetrasi.

\section{Sadranan}

Sadranan pada kenyataannya juga merupakan suatu bentuk/forum komunikasi, yakni wahana di dalam mana banyak orang saling bertemu dan saling berbagi informasi, pengetahuan, perasaan, pandangan-pandangan, bahkan juga harapan-harapan dan saling bergurau dan bercanda. Kegiatan-kegiatan tersebut dapat dilakukan setelah ritual inti dari nyadran selesai yaitu membersihkan makam, mendo'akan yang dikubur, dan menabur bunga. Di Nolokerto dan banyak tempat lain di Kaliwungu tradisi nyadran biasanya dilaksanakan pada hari Jum'at terakhir setiap bulan (tarikh jawa/bulan) tapi teristimewa adalah bulan Ramadhan.

\section{Pertemuan RT sebagai Forum Komunikasi}

Pertemuan RT sebenarnya merupakan gejalaumum dalam masyarakat Indonesia karena memang termasuk merupakan hal yang dianjurkan oleh pemerintah. Pada pertemuan RT biasanya hadir warga masyarakat terutama para bapakbapak yang merupakan kepala keluarga. Waktu penyelenggaraan pada umumnya, termasuk juga di Kaliwungu, memilih pada malam hari sesudah sholat isya', namun sesekali juga diadakan di sore hari karena alasan-alasan tertentu. Kemudian Ketua RT dan tokoh masyarakat setempat (orang yang dituakan) mengambil peran dalam berbagai pembicaraan/pembahasan agenda pertemuan di lingkungan RT setempat. Warga masyarakat senantiasa diberi kesempatan untuk mengemukakan informasi, saran, usulan, dan pendapat berkenaan dan untuk kemajuan bersama termasuk misalnya mengenai pembuatan/ perbaikan saluran, talit, dan pemanfaatan keuangan atau kas RT. Inti karakter pertemuan RT terutama adalah banyak orang saling bertemu dan saling berbagi informasi,usul, saran, dan pendapat mengenai kemajuan dan pembangunan bersama di lingkungan RT setempat. Karena karakter demikian maka forum komunikasi ini dapat dinilai bersifat setengah resmi.

\section{Pandangan Masyarakat Kaliwungu terhadap Globalisasi}

Pada umumnya masyarakat Kaliwungu berpandangan bahwa globalisasi merupakan suatu keniscayaan, merupakan sesuatu yang tidak mungkin dapat dihindari. Mengutip apayang dikatan oleh K.H.M Sholahuddin Humaidulloh (Pengasuh Pondok Pesantren APIK) di peroleh kesan kuat bahwa pandangan yang ada/berkembang di kalangan masyarakat mengenai globalisasi adalah bahwa globalisasi tidak perlu dikhawatirkan karena globalisasi pasti terjadi,globalisasi merupakan suatu yang tidak dapat dihindari karena merupakan sunatullah. Kemudian hal yang lebih penting berkenaan dengan globalisasi, bagi banyak warga masyarakat Kaliwungu, adalah bagaimana menyikapi dan merespon globalisasi secara tepat. Dengan mempersiapkan (sikap dan respon terhadap) akses globalisasi itu termasuk dari sisi aqidah, muamalah, dan akhlak. Globalisasi bersifat multidimensi yang karena itu juga harus direspon 
secara multidimendi pula. Salah satunya sebagai umat Islam harus pandai menyikapi globalisasi dengan berpegang pada Al-Quran dan Al-Hadist untuk merespon globalisasi baik di bidang ekonomi, politik, maupun budaya.

Sementara itu, bagi sebagian kalangan muda di Kaliwungu globalisasi memang dapat memberikan manfaat, globalisasi membuat orang dapat mengetahui berbagai peristiwa penting yang terjadi di wilayah dunia manapun. Namun demikian di bidang budaya maka masyarakat dibanjiri dengan nilai-nilai yang tidak sesuai dengan budaya bangsa termasuk misalnya mode pakaian, kekerasan dan pornografi. Kemudian globalisasi secara ekonomi nampaknya memang membawa manfaat bagi masyarakat yakni berbagai barang kebutuhan hidup dijual secara bebas dan saling berkompetisi sehingga dapat memungkinkan orang atau konsumen memperoleh barang dengan kualitas lebih bagus tetapi dengan harga yang lebih murah.

\section{Pandangan Masyarakat tentang Peran Media Massa dalam Proses Globalisasi}

Pandangan atau penilaian warga masyarakat Kaliwungu mengenai peran media massa dalam proses globalisasi dapat dikatakan lebih menunjukkan kesan bahwa media massa merupakan unsur (agent) globalisasi yang paling utama. Artinya, kebanyakan warga masyarakat di Kaliwungu menilai bahwa media massa, terutama sekali dalam hubungan ini adalah televisi, memang secara kuat memfasilitasi membanjirnya nilai-nilai budaya global mulai dari gaya hidup, model/cara berpakaian, cara berbahasa, kesenian, adatkebiasaan, dan juga menu masakan.

\section{Simpulan dan Saran}

Berkenaan dengan persoalan bagaimana masyarakat Kaliwungu berupaya melestarikan, menjaga identitas kultural mereka terutama dalam hal berbahasa, berpakaian, dan beradat kebiasaan ketika mereka dihadapkan pada derasnya penetrasi nilai-nilai budaya global maka dapat dikatakan bahwa identitas kultural nampaknya bukan merupakan suatu entitas yang memiliki cakupan aspek yang saling berdiri sendiri, saling terpisah antara satu aspek kehidupan dengan aspek kehidupan lainnya. Akan tetapi kecenderungan yang ada justru menununjukkan bahwa identitas kultural merupakan entitas yang memiliki cakupan aspek yang saling bertautan antara satu dengan lainnya. Cara berbusana, misalnya, sangat berkaitan dengan adat kebiasaan, dan adat kebiasaan juga mempengaruhi cara berbahasa. Cara berbusana memiliki hubungan dengan adat-kebiasaan (atau lebih tepatnya adat kebiasaan memengaruhi cara berbusanan oleh sebab jenis pakaian dikenakan untuk kepentingan yang tertentu sifatnya, dan apabila kepentingan berbeda maka sangat mungkin jenis pakaian yang dikenakan juga akan berbeda. Pakaian yang dikenakan oleh seseorang untuk kepentingan menghadiri walimahan (perjamuan), sangat berbeda dengan pakaian yang dikenakan untk kepentingan bekerja misalnya di sawah atau berjualan (berdagang). Namun demikian secara umum dapat dikatakan bahwa cara berbusanan warga masyarakat Kaliwungu sangat bernuansakan nilai-nilai keislaman.

Cara berbahasa sebagai suatu aspek dalam identitas kultural dalam banyak hal memiliki kaitan dengan adat-kebiasaan atau tradisi. Apa yang berkembang di kalangan masyarakat Kaliwungu adalah bahwa nilai-nilai budaya pesisiran (lebih egaliter dan langsung tidak efumistik) serta nilainilai budaya Islam ternyata sangat berpengaruh terhadap cara berbahasa masyarakat Kaliwungu. Berbicara dengan bahasa Jawa Ngoko (bukan krama inggil) yang sering dicampur dengan Kromo Madyo, dan Bahasa Indonesia merupakan gejala yang paling banyak dijumpai (paling umum) di Kaliwungu. Kemudian penggunaan kata-kata dalam bahasa Arab dan/atau bahasa dalam Al-Quran.

Dalam hubungan ini Masjid Besar AlMuttaqien yang terletak di tengah Kota Kaliwungu seolah merupakan penjaga identitas kultural yang paling spektakuler sejauh berkenaan dengan nilainilai keislaman baik dalam kaitan dengan cara berbusana maupun cara berbahasa apalagi dalam kaitan dengat adat kebiasaan. Nilai-nilai keislaman dilestarikan dan juga dikembangkan melalui berbagai acara kegiatan baik di masjid maupun di rumah-rumah (keluarga) penduduk. Berbagai adat kebiasaan atau tradisi seperti syawalan, silaturahmi, sadranan, dan weh-wehan ditransformasikan ke dalam nuansa Islam melalui peran para ulama dan Kiai termasuk para ulama dan Kiai di Masjid Besar Al-Muttaqien dan Pondok Pesanteren APIK.

Selanjutnya, dapat dikatakan bahwa semua dari adat kebiasaan yang ada di masyarakat Kaliwungu, seolah dengan sendirinya memiliki fungsi sebagai bentuk atau forum (ber)komunikasi di antara sesama warga Kaliwungu. Dalam hubungan ini lalu dapat dikatakan bahwa adat kebiasaan notabene adalah juga bentuk identitas kultural yang dilestarikan di Kaliwungu.

Bentuk-bentuk atau forum komunikasi. Kemudian berkenaan dengan persoalan bagaimana bentuk atau forum komunikasi dikembangkan oleh masyarakat Kaliwungu dalam berbagai kesempatan yang memiliki signifikansi dengan upaya pelestarian identitas kultural atau sangat bervariasi termasuk misalnya silaturahmi, syawalan, walimahan, sdranan, weh-wehan, pertemuan trah dan pertemuan RT. Bentuk-bentuk atau forum komunikasi yang berkembang di 
Kaliwungu dapat dikatakan bersifat khas kecuali. Pandangan mengenaiglobalisasi. Dapat dikatakan bahwa masyarakay Kaliwungu pada umumnya memandang bahwa globalisasi merupakan keniscayaan, bahkan sebahai ulama di sini memahaminya sebagai salah satu bentuk/ wujud sunatullah. Globalisasi tidak dapat dihindari atau dielakan. Bagi kebanyakan warga Kaliwungu yang lebih penting berkenaan dengan globalisasi adalah memberikan respon secara tepat; mengambil yang baikdan membuang yang buruk untuk kemanfaatan dan kemajuan masyarakat. Dalam hubungan ini persoalan baik-buruk ditimbang dengan menggunakan nilai keislaman terutam bersumber pada Al-quran dan Al-Hadist. Globalisasi bagi kebanyakan warga Kaliwungu memang membawa unsur-unsur yang buruk/merusak seperti gaya hidup hedonis dan sikap-sikap individualistis seperti yang banyak dipertontonkan di televisi.

Pandangan mengenai peran media massa. Pada umumnya masyarakat Kaliwungu menilai bahwa media massa terutama sekali televisi merupakan unsur (agent) paling utama dari globalisasi. Penetrasi nilai-nilai budaya global difasilitasi oleh media massa terutama televisi yang memberikan informasi mengenai berbagai peristiwa penting serta gambaran-gambaran kehidupan masyarakat lain di dunia. Namun demikian televisi kerapkali membawa nilai budaya asing dalam konteks globalisasi yang tidak sesuai dengan nilai-nilai budaya yang ada bersifat keislaman.

Pada sisi praktis menjaga dan mengembangkan tradisi-tradisi yang sudah ada dan/atau berkembang sejak lama barangkali menjadi hal yang prinsip untuk pengembangan identitas kultural karena muara identitas kultural rupanya justru pada tradisi atau adat kebiasaan. Semua pemangku kepentingan baik dari kalangan pemerintahan, para kiai dan ustad di pondok pesantren dan masjid,maupun para tokoh masyarakat memiliki kewajiban moral untuk upayaupaya pelestarian identitas kultural di Kaliwungu.

\section{Daftar Pustaka}

Barker, C. (1999). Television, Globalization and Cultural identities, Buckibgham:Open University Press.

Comstock, G., and McCombs, M. 'Survey Research" dalam Guido H. Stempel III dan Bruce H. Westley (eds). (1981). Research Methods in Mass communication. Englewood clif, NJ : Prentice-hall Inc.

Ferguson, (2002). "The Mythology About Globalization" dalam Denis McQuail. Mc Quails'Reader in Mass Communicatioan Theory. London : Sage
Publications.

Fiske, J. (1990). Introduction To Communication Studies 2nd ed. London: Routledge.

Henighan, T. (2002). The media, Globalization, and the Problem dan National Identity. (diakses 11 April 2009).

Lechner, F.J . (2002). Globalization and National Identity inthe Netherlands, 1980-2000. (diakses 11 April 2009).

Lindlof, T.R. (1995). Qualitative Communication Research Methods. Thousand Oaks : Sage Publications.

Littlejohn, S.W. (2002). Theories of Human Communication $7^{\text {th }}$.ed. Belmont, CA: Wadsworth Group.

Loughney, J .A. (1998). "Cultural I dentity" dalam Edward Craig (general editor). Routledge Encyclopedia of Philosophy Vol.2. London: Routledge.

Malgaj, L. (2009),"The Impact of Globalization on Cultural Identity", (diakses 23 Desember 2011).

McQuail, D. (2002). Mass Communication Theory 4ed. London: Sage Publications.

Miller, G. (1996). “Case Studies” dalam David Levinson dan Melvin Ember (eds) encyclopedia of Cultural anthropology Vol.4.New York: Henry Holt and Company.

Palmer, E. L. (1998). 'Major Paradigms and issues in television research" dalam J oy Keiko Asamen dan Gordon L. Berry (eds.). Research Paradigms, Television, and Social Behavior. Thousands Oaks: Sage Publications.

Patton, M.Q. (2002). Qualitative Tesearch \& Evaluation Methods 3rd ed. Thousand Oaks: Sage Publication.

Pawito, "Voters' Perception og Television Campaign Reporting", Berita Iptek, No.1, Tahun ke-42, 2001 - LIPI J akarta.

Pawito. (2007). Penelitian Komunikasi Kualitatif. Yogyakarta: Lkis

Pawito. (2008). Komunikasi Politik: media Massa dan Kampanye Pemilihan. Yogyakarya: Penerbit Jalasutra.

Pawito. (2010). Media Massa,Globalisasi, dan Identitas Nasional. Surakarta: UNS Press. 9 Pidato Pengukuhan Guru Besar Teori Komunikasi pada Fakultas IImu Sosial dan IImu Politik Universitas Sebelas Maret Surakarta, 7 Januari 2010).

Thohir, M. Tradisi Syawalan di Jawa", Suara Merdeka 25 Agustus 2012.

Watt, J.H. and Van den Berg, S.J. (1995). Research Methods for Mass Communication Science. Boston: Allyn and Bacon. 